(c) American Dairy Science Association, 2004.

\title{
Effects of Milk Urea Nitrogen and Other Factors on Probability of Conception of Dairy Cows*
}

\author{
K. Guo, E. Russek-Cohen, M. A.Varner, and R. A. Kohn \\ Department of Animal and Avian Sciences, \\ University of Maryland, College Park 20742
}

\begin{abstract}
The objective of this study was to evaluate the relationships between milk urea nitrogen (MUN) and other factors and the probability of conception in dairy cows. Data were retrieved from the Lancaster Dairy Herd Improvement Association (DHIA). A total of 713 dairy herds and 10,271 dairy cows were included in the study. Logistic regression was used to determine the withinherd effects of MUN, milk production, lactation number, and breeding season on the probability of conception for each of 3 services. Within herds, MUN displayed a slight negative association with probability of conception at first service. For example, there was a 2- to 4-percentage unit decrease in conception rate at first service with a $10-\mathrm{mg} / \mathrm{dL}$ increase in MUN. In amongherd regression analysis, there was no effect of MUN on probability of conception. These results suggest that MUN may be related to conditions affecting reproduction of individual cows within a herd. Diet formulation usually would affect MUN equally among all cows at a similar stage of lactation in a herd. Because there was no effect of MUN among herds, diet formulation did not appear to affect conception rate.
\end{abstract}

(Key words: milk urea nitrogen, probability of conception, reproduction)

Abbreviation key: $\mathbf{C R}=$ conception rate.

\section{INTRODUCTION}

Milk urea nitrogen is a by-product of dairy cattle protein metabolism and a reflection of urinary nitrogen excretion (Jonker et al., 1998). It is highly correlated with blood urea nitrogen and plasma urea nitrogen. Excessive feeding of protein can lead to increased MUN concentration (DePeters and Ferguson, 1992; Broderick and Clayton, 1997). Milk urea nitrogen measurement

Received November 20, 2003.

Accepted February 3, 2004.

Corresponding author: R. A. Kohn; e-mail: rkohn@wam.umd.edu.

*A contribution from the Maryland Agricultural Experiment Station. is convenient and noninvasive, and several DHIA laboratories provide MUN as a regular analysis while sampling milk.

Reproductive performance has a substantial impact on economic profitability of dairy farms (Mourits et al., 1997). Jorritsma et al. (2003) have reviewed the influences of metabolic changes during early lactation on reproductive performance. Nutrition management may be an important means to improve dairy cow reproductive performance (Ferguson and Chalupa, 1989). Several studies reported the negative effects of blood urea nitrogen or MUN on reproductive performance in dairy cows and suggested that overfeeding CP caused reproductive stress (Ferguson et al., 1993; Rajala-Schultz et al., 2001). However, others did not find such negative effects of high MUN on fertility of cows (Carroll et al., 1988; Godden et al., 2001).

The previous studies were conducted with a small number of animals $(<200$ to 300$)$ and herds $(<30)$; therefore, our objective was to evaluate the associations of MUN and other factors on probability of conception of dairy cows based on data from a large number of herds.

\section{MATERIALS AND METHODS}

\section{Data Collection}

Data were retrieved from the Lancaster DHIA (Manheim, PA) for herds in Pennsylvania. Cows that were first bred between June 1, 2000 and May 31, 2001 were included in the study. A total of 10,271 cows from 713 herds were selected (from a total of 44,090 cows and 1066 herds) when data on milk production, MUN, pregnancy status, and breeding date were available. Milk urea nitrogen values were measured using Bentley Chemspec Instrument, which is based on a modified Berthelot reaction (Chaney and Marback, 1962) to detect ammonia after urea hydrolysis (Bentley Instruments, Chaska, MN).

The average days open to first service was $91 \mathrm{~d}$, the interval between first and second service was $60 \mathrm{~d}$, and the interval between second and third service was $49 \mathrm{~d}$ (Table 1). Therefore, we used MUN and milk production data from 60 to $90 \mathrm{~d}$ post calving for regression against 
Table 1. Distributions of variables. ${ }^{1}$

\begin{tabular}{lccr}
\hline Variables & \multicolumn{1}{c}{ No. } & Mean & SD \\
\hline Observations per herd & 713 & 14.4 & \\
Milk production at 60 to 90 d (kg/d) & 10,271 & 38.1 & 10.5 \\
MUN at 60 to 90 d (mg/dL) & 10,271 & 13.4 & 3.9 \\
Lactation number & 10,271 & 2.41 & 1.5 \\
Service number of current pregnancy & 10,271 & 2.77 & 2.0 \\
Days to first service (d) & 10,271 & 90.6 & 48.7 \\
Interval between first and second service (d) & 6581 & 59.9 & 34.3 \\
Interval between second and third service (d) & 4138 & 49.0 & 99.9 \\
Calving interval (d) & 9174 & 451.3 & 103.1 \\
Days open (d) & 10,271 & 177 & \\
Average conception rate at first service & 10,271 & $31 \%$ & $33 \%$ \\
Average conception rate at second service & 6581 & $35 \%$ & 6654 \\
Average conception rate at third service & 4138 & 23,785 & \\
305-d mature equivalent milk production (kg) & 10,271 & & \\
\hline
\end{tabular}

\footnotetext{
${ }^{1}$ Milk production and MUN values were test-day measurements at 60 to $90 \mathrm{~d}$ after calving (within $30 \mathrm{~d}$ before the first service).

${ }^{2}$ Standard deviation within herd.
}

the probability of conception at first service. By the same token, we used MUN and milk production from 120 to $150 \mathrm{~d}$ and 170 to $200 \mathrm{~d}$ after calving for regression against probability of conception at second service and third service, respectively. We chose not to use the MUN value at breeding because typically MUN value increases and then declines during lactation (Jonker et al., 1998). Thus, higher MUN at breeding may be confounded with fewer days in milk at breeding and therefore reduced probability on conception.

The time range for the study was divided into 4 seasons: winter (December, January, and February), spring (March, April, and May), summer (June, July, and August), and fall (September, October, and November).

\section{Statistical Analysis}

Within-herd logistic regression analyses. The probability of conception at each service was analyzed separately using logistic regression of PROC GENMOD of SAS (2000). The full model is listed as follows:

$$
\begin{gathered}
\ln \left(\frac{p}{1-p}\right)=I+L+S+N+M+L S \\
+L N+L M+S N+S M+N M+L S N+L S M \\
+S M N+L S M N+N^{2}+M^{2}+L N^{2}+L M^{2}+H+e
\end{gathered}
$$

where

$p=$ probability of conception for a cow;

$I=$ intercept of the model;

$L=$ fixed effect of the lactation number;

$S$ = fixed effect of season;
$N=$ MUN at 60 to 90,120 to 150 , and 170 to $200 \mathrm{~d}$ post calving for first, second, and third service, respectively; and

$M=$ daily milk production at 60 to 90,120 to 150 , and 170 to $200 \mathrm{~d}$ post calving for first, second, and third service, respectively;

$H=$ random effect of herd; and

$e=$ error.

A GEE analysis in PROC GENMOD was used to account for correlation among cows within a herd. All quantitative variables were centered to reduce multicollinearity (SAS, 2000). Insignificant $(P>0.05)$ terms were removed by stepwise elimination. Logistic regression fits the logit of the probability of conception to a linear model of factors.

Among-herd analyses. To analyze the among-herd effects, means for each herd were computed for conception rate (CR), MUN (60 to $90 \mathrm{~d}, 120$ to 150 , and 170 to $200 \mathrm{~d}$ ), milk production (60 to 90,120 to 150 , and 170 to $200 \mathrm{~d}$ ), and lactation number at first, second, and third services. Medians were used for days open because they were not normally distributed and because sometimes cows were culled prior to next service. Herds with data from $<3$ cows were dropped. A total of 506 herds comprised of 9810 cows were included in the analysis.

Conception rate and days open were analyzed using multiple regression model of JMP (2000) according to the following model:

$$
\begin{gathered}
Y=I+L+N+N^{2}+M+M^{2}+L N \\
+L M+N M+L N^{2}+L M^{2}+L N M+e
\end{gathered}
$$

where 
Table 2. Within herd logistic regression for probability of conception at first service in dairy cows (713 herds; 10,271 cows).

\begin{tabular}{llll}
\hline Factor & Estimate & SE & $P<$ \\
\hline Lactation no. & 0.053 & 0.03 & 0.06 \\
MUN $^{1}$ & -0.020 & 0.008 & 0.01 \\
Milk production $\left(\right.$ milk) $^{1}$ & -0.021 & 0.005 & 0.0001 \\
Season & & & \\
Winter & 0 & 0 & \\
Spring & 0.66 & 0.06 & 0.0001 \\
Summer & -0.28 & 0.1 & 0.02 \\
Fall & -0.36 & 0.1 & 0.001 \\
Lactation no. $\times$ season & & & \\
Lactation no. $\times$ winter & 0 & 0 & \\
Lactation no. $\times$ spring & -0.056 & 0.03 & 0.05 \\
Lactation no. $\times$ summer & 0.018 & 0.07 & 0.1 \\
Lactation no. $\times$ fall & -0.091 & 0.05 & 0.8 \\
Lactation no. $\times$ milk & -0.0002 & 0.003 & 0.9 \\
Season $\times$ milk & & & \\
Winter $\times$ milk & 0 & 0 & \\
Spring $\times$ milk & 0.012 & 0.001 & 0.03 \\
Summer $\times$ & 0.016 & 0.01 & 0.2 \\
Fall $\times$ milk & -0.010 & 0.01 & 0.3 \\
Lactation no. $\times$ season $\times$ milk & & & \\
Lactation no. $\times$ winter $\times$ milk & 0 & 0 & \\
Lactation no. $\times$ spring $\times$ milk & -0.002 & 0.004 & 0.6 \\
Lactation no. $\times$ summer $\times$ milk & -0.028 & 0.006 & 0.0001 \\
Lactation no. $\times$ fall $\times$ milk & -0.0008 & 0.005 & 0.2 \\
\hline
\end{tabular}

${ }^{1}$ Milk production and milk urea nitrogen (MUN) were the test-day measurements at 60 to $90 \mathrm{~d}$ after calving.

${ }^{2}$ Seasonal effects were estimated by using winter as the baseline.

$Y=\mathrm{CR}$ or median days open to first, second, or third service;

$\mathrm{I}=$ intercept of the model;

$L=$ fixed effect of the lactation number;

$N=$ fixed effect of MUN at 60 to 90,120 to 150 , and 170 to $200 \mathrm{~d}$ post calving for first, second, and third service, respectively;

$M=$ fixed effect of daily milk production at 60 to 90 , 120 to 150 , and 170 to $200 \mathrm{~d}$ post calving for first, second, and third service, respectively; and

$e=$ error term

Partial $F$ tests were used to select the variables that were significantly related to conception rate and days open at first, second, and third service, respectively.

\section{RESULTS}

Among all cows included in the study, a mean of 2.8 services were required for pregnancy. The overall CR were 31,33 , and $35 \%$ for first, second, and third service, respectively (Table 1 ).

\section{Within-Herd Analysis}

Among cows within herds, the effects on probability of conception at first to third service are shown in Tables 2 to 4 , respectively. There was a negative association
Table 3. Within-herd logistic regression for probability of conception at second service in dairy cows (496 herds; 6358 cows).

\begin{tabular}{lcll}
\hline Factor & Estimate & $\mathrm{SE}$ & $P<$ \\
\hline Lactation no. & -0.007 & 0.03 & 0.8 \\
${\text { Milk production }(\text { milk })^{1}}^{1}$ & -0.022 & 0.008 & 0.005 \\
Milk $\times$ milk & 0.003 & 0.0002 & 0.3 \\
Season $^{2}$ & & & \\
Winter & 0 & 0 & \\
Spring & 0.668 & 0.08 & 0.0001 \\
Summer & 0.434 & 0.09 & 0.0001 \\
Fall & -0.040 & 0.1 & 0.7 \\
Milk $\times$ season & & & \\
Milk $\times$ winter & 0 & 0 & \\
Milk $\times$ spring & 0.013 & 0.009 & 0.1 \\
Milk $\times$ summer & 0.005 & 0.01 & 0.6 \\
Milk $\times$ fall & 0.029 & 0.01 & 0.02 \\
Lactation no. $\times$ milk & 0.0002 & 0.002 & 0.9 \\
Lactation no. $\times$ milk $\times$ milk & -0.0003 & 0.0002 & 0.04 \\
\hline
\end{tabular}

${ }^{1}$ Milk production was the test-day measurement at 120 to $150 \mathrm{~d}$ after calving.

${ }^{2}$ Seasonal effects were estimated by using winter as the baseline.

of MUN with CR at first service (Figure 1) but not in subsequent services. For example, a change in MUN from 9 to $18 \mathrm{mg} / \mathrm{dL}$ resulted in a 2.2- or 4.4-percentage unit change in conception rate at first service for lowproducing cows bred in spring and high-producing cows bred in fall, respectively (Figure 1). Within herds, there was a negative association of milk production with probability of conception at all three services (Tables 2 to 4; Figure 2). Seasonal effects were significant for all three services, with higher CR in the spring (Tables 2 to 4 ; Figure 1). There was an interaction of lactation number by season by milk production for first service (Figure 3).

\section{Among-Herd Analyses}

Among herds, the main linear effects on probability of conception at first service were not significant $(P>$ 0.05 ), but there was a positive quadratic effect of milk production. Lactation number by milk production and lactation number by MUN interactions were also sig-

Table 4. Within-herd logistic regression for probability of conception at third service in dairy cows (460 herds; 4138 cows).

\begin{tabular}{llll}
\hline Factor & Estimates & SE & $P<$ \\
\hline Milk production $^{1}$ & -0.017 & 0.004 & 0.001 \\
Season $^{2}$ & 0 & 0 & \\
Winter & 0.559 & 0.09 & 0.001 \\
Spring & 0.334 & 0.1 & 0.001 \\
Summer & 0.653 & 0.1 & 0.001 \\
Fall & &
\end{tabular}

${ }^{1}$ Milk production was the test-day measurement at 170 to $200 \mathrm{~d}$ after calving.

${ }^{2}$ Seasonal effects were estimated by using winter as the baseline. 


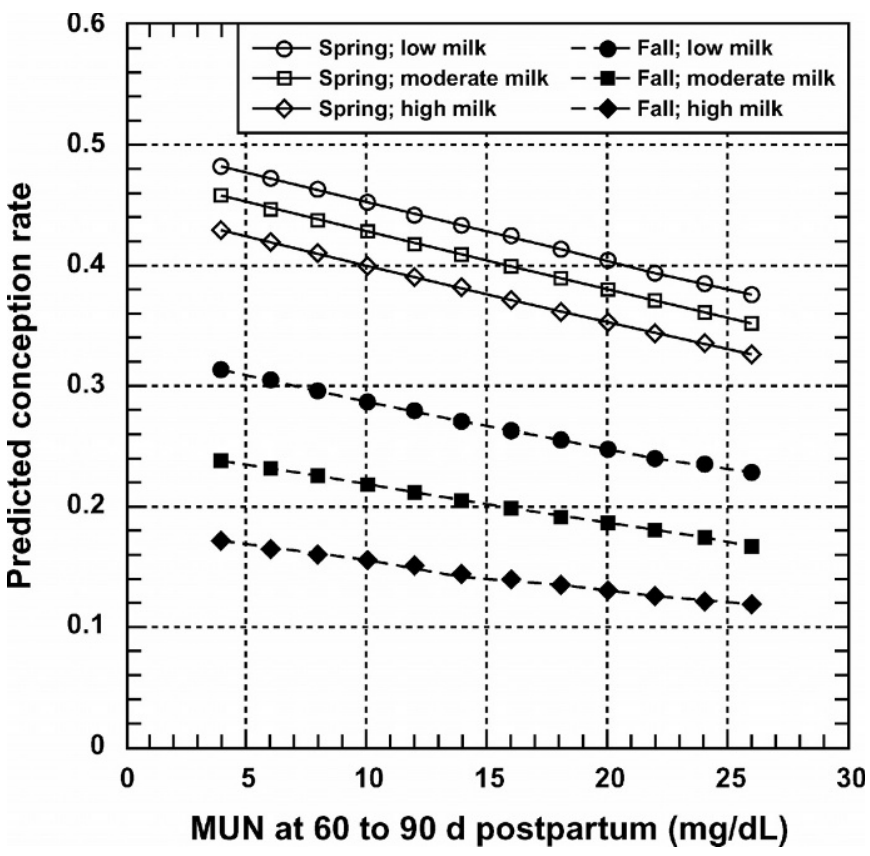

Figure 1. The within-herd milk urea nitrogen (MUN) effect and interaction of milk production and season (spring and fall) on conception rate at first service. Lactation $=2$, low milk production $=25.5$ $\mathrm{kg}$, moderate milk production $=37.7 \mathrm{~kg}$, and high milk production $=$ $51.4 \mathrm{~kg}$. Low, moderate, and high milk production are reflections of the lower $10 \%$, median, and upper $10 \%$ of all observations, respectively. Probability of conception was calculated from the logistic regression model; non-parallel lines do not necessarily represent interactions.

nificant (Table 5). For the second service, only milk production had a negative impact on CR (Table 6). There was a quadratic effect of milk production on CR at third service (Table 7).

In regression analysis on days open to first service (Table 8), lactation number and MUN had no effect ( $P$ $>0.05$ ); however, milk production had a negative linear effect on days open and a positive quadratic effect. There were lactation number $\times$ MUN and milk production $\times$ MUN interactions (Figure 4). For the second service, milk production had a positive quadratic effect on days open (Table 9). No significant effects were found at third service.

\section{DISCUSSION}

\section{MUN Effect}

Jorritsma et al. (2003) have reviewed the influences of urea and ammonia on reproduction during early lactation. Larson et al. (1997) found that non-pregnant cows with low progesterone post breeding were often associated with high MUN. Elrod and Butler (1993) suggested that high MUN may be associated with a

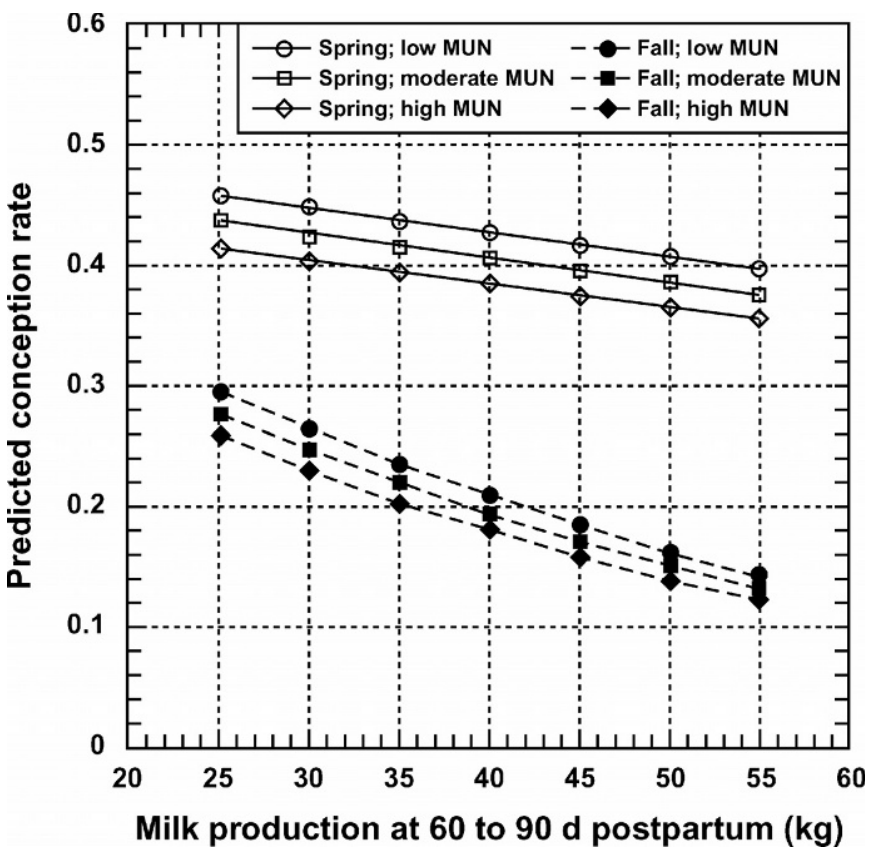

Figure 2. The within-herd milk urea nitrogen (MUN) effect and the interaction of milk production and season (spring and fall) on conception rate at first service. Lactation $=2$, low MUN $=9 \mathrm{mg} / \mathrm{dL}$, moderate $\mathrm{MUN}=13.5 \mathrm{mg} / \mathrm{dL}$, and high $\mathrm{MUN}=18 \mathrm{mg} / \mathrm{dL}$. Low, moderate, and high MUN are reflections of the lower 10\%, median, and upper $10 \%$ of all observations, respectively.

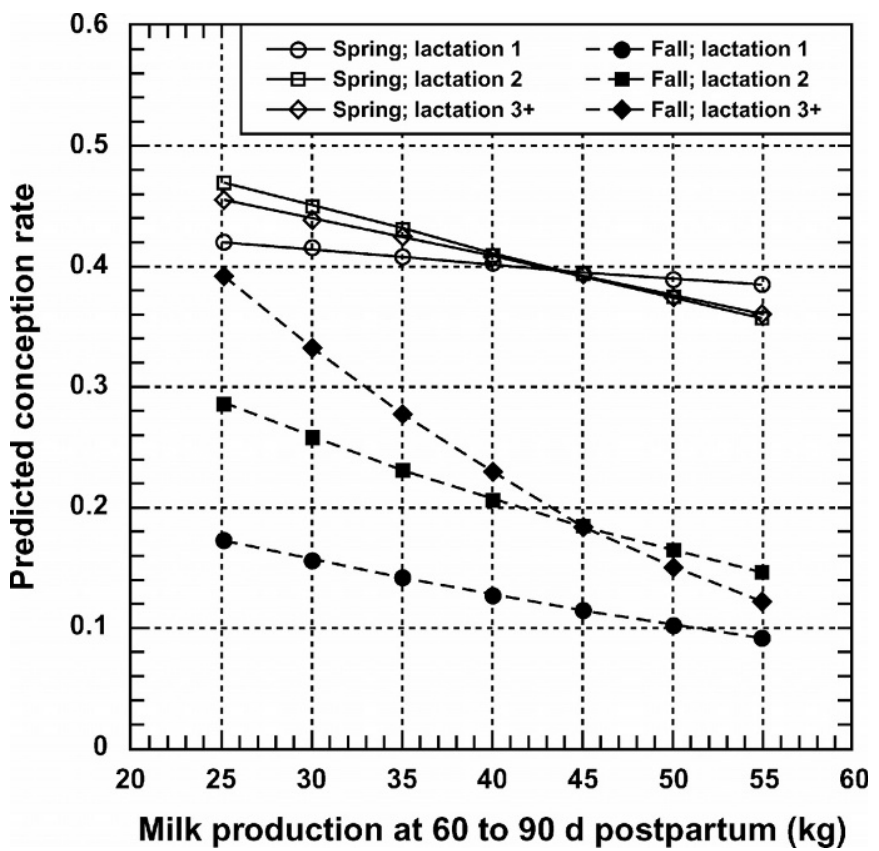

Figure 3. Within-herd milk production by lactation number by season (spring and fall) interaction on conception rate at first service. 
Table 5. Among-herd regression on conception rate at first service (506 herds; 9810 cows).

\begin{tabular}{lcll}
\hline Term & Estimate & SE & $P<$ \\
\hline Intercept & 0.40 & 0.01 & 0.0001 \\
${\text { Milk production }(\text { milk })^{1}}_{\text {MUN }^{1}}$ & -0.001 & 0.002 & 0.5 \\
Lactation no. & 0.005 & 0.005 & 0.3 \\
Milk $\times$ milk & 0.02 & 0.02 & 0.3 \\
Lactation no. $\times$ milk & 0.0005 & 0.0001 & 0.004 \\
Lactation no. $\times$ MUN & 0.007 & 0.003 & 0.006 \\
\hline
\end{tabular}

${ }^{1}$ Milk production and milk urea nitrogen (MUN) were the test-day measurements at 60 to $90 \mathrm{~d}$ after calving.

decrease in uterine $\mathrm{pH}$, which could make the environment within the uterus unsuitable for early embryo development. Previous research has also shown that cows within herds with high MUN were associated with reduced probability of conception at first service, but not at subsequent services (Ferguson et al., 1993). In this study, we saw a negative effect of MUN on conception rate at first service among cows within herds, but no such effects were found at second and third service. In among-herd analyses, MUN had minimal effect on conception rate, but was associated with greater days open among high-producing herds. These results agree with the hypothesis that urea affects cleavage and blastocyst formation but not necessarily early oocyte development (Jorritsma et al., 2003).

High MUN may be caused by many factors. Excessive protein intake is a common nutritional factor (Jonker et al., 1998). Blood urea nitrogen or plasma urea nitrogen, which is the origin of MUN, may also be affected by diseases or medicines from treatments (Vestweber et al., 1989). Any disease or body condition that reduces glomerular filtration such as dehydration, heart disease, and renal disease or any condition that increases protein catabolism can result in increased blood urea nitrogen level (Fraser, 1991). In this geographic region, most herds $(75 \%)$ are fed a single diet (Jonker et al., 2002), and certainly most cows within a herd are fed the same diet during the same stage of lactation (e.g., 60 to $90 \mathrm{~d}$ postpartum). Therefore, ration formulation is likely to affect MUN equally among all cows in the herd at a similar stage of lactation. Conversely, any number of factors including health or energy balance

Table 6. Among-herd regression on conception rate at second service (305 herds; 5737 cows).

\begin{tabular}{lcll}
\hline Term & Estimate & $\mathrm{SE}$ & $P<$ \\
\hline Intercept $_{\text {Milk production }}{ }^{1}$ & 0.504 & 0.01 & 0.0001 \\
\hline
\end{tabular}

${ }^{1}$ Milk production was the test-day measurement at 120 to $150 \mathrm{~d}$ after calving.
Table 7. Among-herd regression on conception rate at third service (207 herds; 2840 cows).

\begin{tabular}{lcll}
\hline Term & Estimate & SE & $P<$ \\
\hline Intercept & 0.577 & 0.02 & 0.0001 \\
Milk production $\left(\right.$ milk) $^{1}$ & -0.004 & 0.003 & 0.1 \\
Milk $\times$ milk & 0.0006 & 0.0003 & 0.03 \\
\hline
\end{tabular}

${ }^{1}$ Milk production was the test-day measurement at 170 to $200 \mathrm{~d}$ after calving.

can affect MUN among individual cows within a herd (Collard et al., 2000; Stockham and Scott, 2002).

In the present study, we detected a negative association of MUN with CR at first service among cows within herds. This implies that the within-herd negative association of MUN with probability of conception during early lactation could relate to the status or condition of individual cows. Negative energy balance and illnesses are common during 60 to $90 \mathrm{~d}$ postcalving (Waltner et al., 1993; Collard et al., 2000). Some illnesses may result in higher MUN or BUN as well as reproductive problems (Finco et al., 1997; Stockham and Scott, 2002). When cows are at second or third service, increased energy supply may reduce the stress from milk production. As body condition improves, the incidence of illness may be less likely, and the relationship between MUN and CR would disappear.

Diet formulation is usually similar for all animals in a similar stage of lactation within a herd. Therefore, among-herd effects are likely to reflect diet differences. Among herds, CR was largely unaffected by MUN, although there was a significant negative interaction of MUN and lactation number for CR at first service. The magnitude of this effect was negligible. Thus, diet formulation appeared to have a minimal effect on CR.

Although diet formulation did not appear to affect $\mathrm{CR}$, it may have been associated with days open at first service. Figure 4 shows that herds with high milk production $(>40 \mathrm{~kg}$ ) from 60 to $90 \mathrm{~d}$ postpartum had increased days open at first service, especially when those herds also had high MUN. These high-producing

Table 8. Among-herd regression on days open to the first service (506 herds; 9810 cows).

\begin{tabular}{llll}
\hline Term & Estimate & $\mathrm{SE}$ & $P<$ \\
\hline Intercept & 84.0 & 1.4 & 0.0001 \\
Milk production (milk) $^{1}$ & -0.410 & 0.2 & 0.05 \\
MUN $^{1}$ & 0.218 & 0.5 & 0.7 \\
Lactation \# $_{\text {Milk } \times \text { milk }}$ & -0.145 & 0.7 & 0.9 \\
Milk $\times$ MUN & 0.057 & 0.02 & 0.003 \\
Lactation no. $\times$ MUN & 0.153 & 0.07 & 0.02 \\
\hline
\end{tabular}

${ }^{1}$ Milk production and milk urea nitrogen (MUN) were the test-day measurements at 60 to $90 \mathrm{~d}$ after calving. 


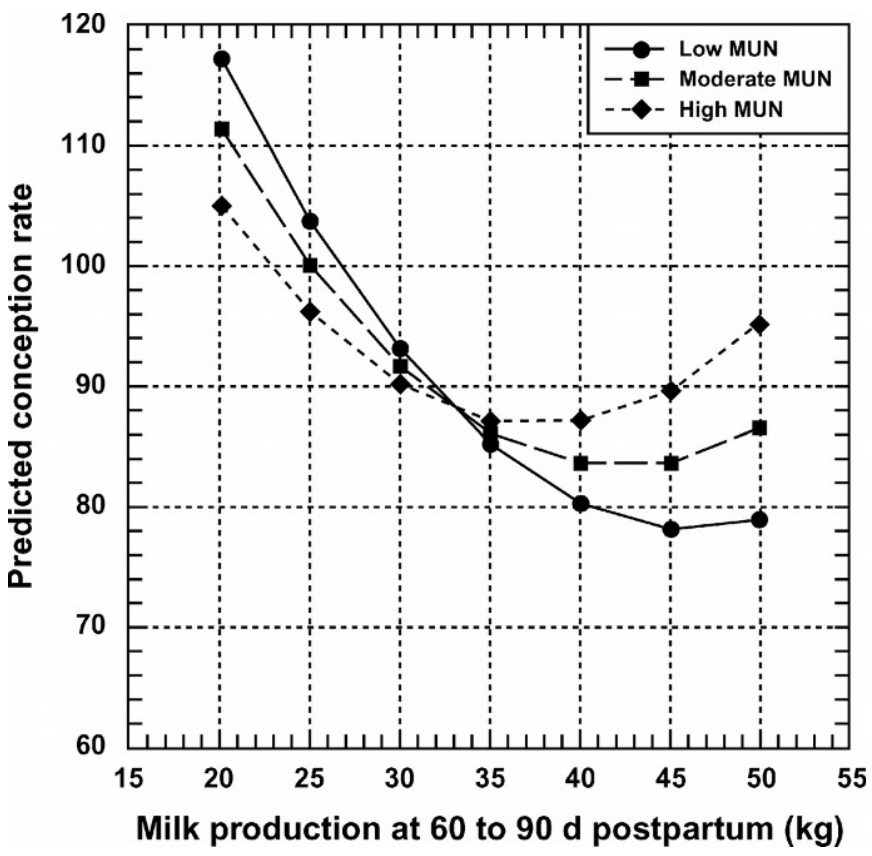

Figure 4. Among-herd interactions of milk production and milk urea nitrogen (MUN) on days open at first service. Low MUN $=10.7$ $\mathrm{mg} / \mathrm{dL}$, moderate MUN $=13.7 \mathrm{mg} / \mathrm{dL}$, and high $\mathrm{MUN}=17 \mathrm{mg} / \mathrm{dL}$. Low, moderate, and high MUN are reflections of the lower $10 \%$, median, and upper $10 \%$ of all observations, respectively.

herds might have delayed estrus because of negative energy balance caused by high milk production. The high MUN associated with this effect might have resulted from high-protein diets, which exacerbated the negative energy balance due to the energy required to excrete nitrogen (Tyrrell et al., 1970). This leaves open the possibility that feeding high-protein diets can affect reproduction by increasing the days open at first service.

\section{Milk Production Effect}

The negative effect of milk production on conception rate has long been recognized (Spalding et al., 1975). In the present study, high milk production of individual cows within herds was associated with reduced probability of conception at all three services (Figure 2; Ta-

Table 9. Among-herd regression on days open to the second service (305 herds; 5737 cows).

\begin{tabular}{lcll}
\hline Term & Estimate & SE & $P<$ \\
\hline Intercept & 135.2 & 2.6 & 0.0001 \\
Milk production (milk) & -0.369 & 0.4 & 0.3 \\
Milk $\times$ milk & 0.087 & 0.03 & 0.01 \\
\hline
\end{tabular}

${ }^{1}$ Milk production was the test-day measurement at 120 to $150 \mathrm{~d}$ after calving. bles 2 to 4). During early lactation, dietary energy intake does not meet energy requirements for increasing milk production. As a result, body fat is mobilized. High producing dairy cows have more severe negative energy balance, which was shown to reduce progesterone secretion and the luteal support for the uterus during pregnancy, thereby lowering the CR (Villa-Godoy et al., 1988; Spicer et al., 1990).

Herds that are well managed can maintain reproduction even in the face of high milk production. Among herds, the positive quadratic association of milk production with $\mathrm{CR}$ at first and third service might have been due to the fact that herds with effective reproduction programs can have higher culling rates and shorter calving intervals. The contrasting negative association of milk production with $\mathrm{CR}$ at second service might have been due to the reduced CR from the stress of higher milk production.

This interplay of milk production and reproduction among herds is also apparent for days open. In this study, number of days open was positively associated with milk production among herds with cows averaging $>45 \mathrm{~kg} / \mathrm{d}$ during first and second service. Negative energy balance that results from high milk production can delay the estrous cycle, therefore prolonging days open (Butler and Smith, 1989). Producers with highproducing cows may choose to delay breeding compared with other producers. However, at lower levels of milk production, number of days open was negatively associated with milk production at first and second service. This latter observation is consistent with Laben et al. (1982), who indicated that, on average, the highestyielding herds had 21 fewer days open than the lowproducing herds. Better reproduction enables greater culling rates and thus higher milk production.

\section{Lactation Number Effect}

Gwazdauskas et al. (1975) indicated that the reproductive performance (CR) decreased as cows grew older. Ray et al. (1992) found that first and sixth lactation cows had the highest number of services per conception, and second to fifth lactation cows had better reproductive performance. In the current study, lactation number had a near significant positive effect and strong interaction with breeding season and milk production on CR among cows within herds at first service. Conception rate was lowest among first lactation cows and increased as cows were more mature at second lactation. However, after second lactation, the effect of lactation number varied greatly under the influences of milk production and breeding season (Figure 3). Similar interaction with milk production can also be found in within-herd analysis at second service and among-herd 
analyses. This implies that lactation number, as an indicator of maturity, might not be the primary factor affecting reproductive performance of dairy cows; however, it might be important to consider while analyzing other factors, such as milk production and breeding season.

\section{Seasonal Effect}

The reproductive performance of dairy cows fluctuated throughout the year. Logistic regression indicated that cows first bred in winter and spring had much higher CR than cows bred in summer and fall. Previous research (Thatcher, 1974; Ray et al., 1992) reported similar results. Rajala-Schultz et al. (2001) also reported that cows calving in summer were least likely to conceive.

Climatic temperature change is associated with fertility (Thatcher, 1974). High temperature in the summer above the thermoneutral zone could significantly reduce CR in dairy cows (Cavestany et al., 1985). Monty and Wolf (1974) indicated that cows calving in cool weather had fewer services per conception than cows that calved in hot weather. Cool weather $12 \mathrm{~d}$ prior to breeding or 4 to $6 \mathrm{~d}$ after AI was beneficial for reproductive performance (Monty and Wolf, 1974).

The results of this study agree with previous studies (Thatcher, 1974; Cavestany et al., 1985) that showed that cows in early lactation (first service) that had been bred in relatively hot weather (summer and fall) had lower CR than did those bred in cooler weather (winter and spring). However, cows at second and third service during summer and fall did not show the same negative effects on $\mathrm{CR}$ as at first service. At second or third service, cows might have been less influenced by the stress of negative energy balance as they gained sufficient energy to cope with the environmental changes. Therefore, high temperature in summer or fall did not have the same negative effect on probability of conception.

\section{CONCLUSION}

Within herd, milk production and MUN (60 to $90 \mathrm{~d}$ after calving) had negative effects on conception rate of dairy cows at first service. Among herds, MUN interacted with milk production and lactation number on days open to first service. The results suggest that the negative effect of MUN on reproduction relates to the status or condition of individual cows. High MUN among herds, which might result from diet formulation, was not associated with reduced conception rates but was associated with a slight increase in days open to first service in high-producing herds.

\section{ACKNOWLEDGMENTS}

The research data for this study were provided by Lancaster DHIA.

\section{REFERENCES}

Broderick, G. A., and M. K. Clayton. 1997. A statistical evaluation of animal and nutritional factors influencing concentrations of milk urea nitrogen. J. Dairy Sci. 80:2964-2971.

Butler, W. R., and R. D. Smith. 1989. Interrelationships between energy balance and postpartum reproductive function in dairy cattle. J. Dairy Sci. 72:767-783.

Carroll, D. J., B. A. Barton, G. W. Anderson, and R. D. Smith. 1988 Influence of protein intake and feeding strategy on reproductive performance of dairy cows. J. Anim. Sci. 71:3470-3481.

Cavestany, D., A. B. El-Wishy, and R. H. Foote. 1985. Effect of season and high environmental temperature on fertility of Holstein cattle. J. Dairy Sci. 68:1471-1478.

Chaney, A. L., and E. P. Marback. 1962. Modified reagents for determination of urea and ammonia. Clin. Chem. 8:130-132.

Collard B. L., P. J. Boettcher, J. C. M. Dekkers, D. Petitclerc, and L. R. Schaeffer. 2000. Relationships between energy balance and health traits of dairy cattle in early lactation. J. Dairy Sci. 83:2683-2690.

DePeters, E. J., and J. D. Ferguson. 1992. Nonprotein nitrogen and protein distribution in the milk of cows. J. Dairy Sci. 75:31293209

Elrod, C. C., and W. R. Butler. 1993. Reduction of fertility and alteration of uterine $\mathrm{pH}$ in heifers fed excess ruminally degradable protein. J. Anim. Sci. 71:694-701.

Ferguson, J. D., and W. Chalupa. 1989. Impact of protein nutrition on reproduction in dairy cows. J. Dairy Sci. 72:746-766.

Ferguson, J. D., D. T. Galligan, T. Blanchard, and M. Reeves. 1993. Serum urea nitrogen and conception rate: The usefulness of test information. J. Dairy Sci. 76:3742-3746.

Finco D. R., J. J. Kaneko, J. W. Harvey, and M. L. Bruss. 1997. Kidney function. Pages 468-472 in Clinical Biochemsitry of Domestic Animals, 5th ed. Academic Press, San Diego, CA.

Fraser, C. M. ed. 1991. The Merck Veterinary Manual, 7th ed. Merck \& Co., Rahway, NJ.

Godden, S. M., D. F. Kelton, K. D. Lissemore, J. S. Walton, K. E. Leslie, and J. H. Lumsden. 2001. Milk urea testing as a tool to monitor reproductive performance in Ontario dairy herds. J. Dairy Sci. 84:1397-1406.

Gwazdauskas, F. C., C. J. Wilcox, and W. W. Thatcher. 1975. Environmental and managemental factors affecting conception rate in a subtropical climate. J. Dairy Sci. 58:88-95.

$\mathrm{JMP}^{\circledR}$ User's Guide: Statistics and Graphics Guide, Version 4. 2000. SAS Inst., Inc., Cary, NC.

Jonker, J. S., R. A. Kohn, and R. A. Erdman. 1998. Using milk urea nitrogen to predict nitrogen excretion and utilization efficiency in lactating dairy cows. J. Dairy Sci. 81:2681-2692.

Jonker, J. S., R. A. Kohn, and J. High. 2002. Dairy herd management practices that impact nitrogen utilization efficiency. J. Dairy Sci. $85: 1218-1226$.

Jorritsma, R., T. Wensing, T. A. M. Kruip, P. L. A. M. Vos, and J. P. T. M. Noordhuizen. 2003. Metabolic changes in early lactation and impaired reproductive performance in dairy cows. Vet. Res. 34:11-26.

Laben, R. L., R. D. Shanks, P. J. Berger, and A. E. Freeman. 1982. Factors affecting milk yield and reproductive performance. J. Dairy Sci. 65:1004-1015.

Larson, S. F., W. R. Butler, and W. B. Currie. 1997. Reduced fertility associated with low progesterone postbreeding and increased milk urea nitrogen in lactating cows. J. Dairy Sci. 80:1288-1295.

Monty, D. E., and L. K. Wolff. 1974. Summer heat stress and reduced fertility in Holstein-Friesian cows in Arizona. Am. J. Vet. Res. 35:1495-1503.

Mourits, M. C. M., A. A. Dijkhuizen, R. B. M. Huirne, and D. T. Galligan. 1997. Technical and economic models to support heifer 
management decisions: Basic concepts. J. Dairy Sci. 80:14061415.

Rajala-Schultz, P. J., W. J. A. Saville, G. S. Frazer, and T. E. Wittum. 2001. Association between milk urea nitrogen and fertility in Ohio dairy cows. J. Dairy Sci. 84:482-489.

Ray, D. E., T. J. Halbach, and D. V. Armstrong. 1992. Season and lactation number effects on milk production and reproduction of dairy cattle in Arizona. J. Dairy Sci. 75:2976-2983.

SAS/STAT ${ }^{\circledR}$ User's Guide: Statistics, Version 8. 2000. SAS Inst., Inc., Cary, NC.

Spalding, R. W., R. W. Everett, and R. H. Foote. 1975. Fertility in New York artificially inseminated Holstein herds in dairy herd improvement. J. Dairy Sci. 58:718-723.

Spicer, L. J., W. B. Tucker, and G. D. Adams. 1990. Insulin-like growth factor-I in dairy cows: Relationship among energy balance, body condition, ovarian activity, and estrous behavior. J. Dairy Sci. 73:929-937.
Stockham, S. L., and M. A. Scott. 2002. Pages 289-294 in Fundamentals of Veterinary Clinical Pathology. Iowa State Press, Ames.

Thatcher, W. W. 1974. Effects of season, climate and temperature on reproduction and lactation. J. Dairy Sci. 57:304-307.

Tyrrell, H. F., P. W. Moe, and W. P. Flatt. 1970. Influence of excess protein intake on energy metabolism of the dairy cow. Pages 6871 in Publication 16. European Assoc. Anim. Prod., London.

Vestweber, J. G. E., F. K. Al-Ani, and D. E. Johnson 1989. Udder edema in cattle: Effects of diuretics (furosemide, hydrochlorothiazide, acetazolamide, and 50\% dextrose) on serum and urine electrolytes. Am. J. Vet. Res. 50:1323-1328.

Villa-Godoy, A., T. L. Hughes, R. S. Emery, L. T. Chapin, and R. L. Fogwell. 1988. Association between energy balance and luteal function in lactating dairy cows. J. Dairy Sci. 71:1063-1072.

Waltner, S. S., J. P. McNamara, and J. K. Hillers. 1993. Relationships of body condition score to production variables in high producing Holstein dairy cattle. J. Dairy Sci. 76:3410-3419. 